Published in "Clinical Anatomy 30(3): 300-302, 2017"

which should be cited to refer to this work.

\title{
Human Anatomy Nomenclature Rules for the Computer Age
}

\author{
PAUL E. NEUMANN, ${ }^{1} *$ ROBERT BAUD, ${ }^{2,3}$ AND PIERRE SPRUMONT ${ }^{2}$ \\ ${ }^{1}$ Department of Medical Neuroscience, Dalhousie University, Halifax, Nova Scotia, Canada \\ ${ }^{2}$ Anatomy, Department of Medicine, University of Fribourg, Fribourg, Switzerland \\ ${ }^{3}$ SIB Text Mining, Swiss Institute of Bioinformatics, Geneva, Switzerland
}

\begin{abstract}
Information systems are increasing in importance in biomedical sciences and medical practice. The nomenclature rules of human anatomy were reviewed for adequacy with respect to modern needs. New rules are proposed here to ensure that each Latin term is uniquely associated with an anatomical entity, as short and simple as possible, and machine-interpretable. Observance of these recommendations will also benefit students and translators of the Latin terms into other languages.
\end{abstract}

\section{Key words: anatomical nomenclature; anatomical terminology; Latin anatomi- cal terms}

The purpose of an international standard nomenclature or terminology in a scientific field is to ensure clear communication. Therefore, two important characteristics are uniformity and stability. The rules of human anatomical nomenclature created by the Nomenclature Commission of the Anatomische Gesellschaft (the German-language Anatomical Society) in the process of writing the first Nomina Anatomica (Basle Nomina Anatomica or BNA; His, 1895). These rules were essentially adopted by the International Anatomical Nomenclature Committee (IANC, 1956). The IANC strengthened the bias of BNA against eponyms by banning them from the anatomical nomenclature. Although there are exceptions to all of the rules in the anatomical terminology, these rules (see Table 1) continue unchanged.

The rules of the international codes of nomenclature in botany (ICN, 2012), zoology (ICZN, 1999), and bacteriology (ICNB, 1992) are more extensive than the rules of human anatomical nomenclature. The naming rules for species and other taxa of living things may need to be more defined and strictly enforced because new species continue to be described and the taxonomies are frequently revised; however, expansion of the set of rules of anatomical nomenclature and better observance of these rules could be beneficial for the field and for others that use the terminologies of the International Federation of Associations of Anatomists (IFAA).

The number of exceptions to the anatomical nomenclature rules has increased in more recent IFAA terminologies. Exceptions to the existing rules are generally made for the convenience of those who have already studied anatomy; however, these exceptions are a hurdle to students and other novice users of anatomical terms. Anatomy terminology rules need amendments to make the terms simpler and clearer for students and translators, and for advances toward a machineinterpretable anatomical terminology. Here, we propose a new basic rule and a set of grammatical rules for human anatomical nomenclature (see Table 2 ).

The proposed Rule 8 would seem to be axiomatic, a partner of Rule 1 . There should be a one-to-one relationship between official terms and named anatomical entities. But the rule needs to be stated because it has not been fully observed in the IFAA terminologies. Examples include Femur and Pelvis. Because the Latin term Femur is used as the official term for the thigh, it should not also be used as a Latin alternative (or synonym) of Os femoris (thigh-bone). This does not mean that femur cannot continue to be the English equivalent of Os femoris. The Latin term Pelvis is used both for a principal part of the Truncus, and for the bony structure that surrounds that body part. The bony structure should be renamed, perhaps as Pelvis ossea (bony pelvis).

Homonyms are also problematic in nomenclatures. The anatomical terminology uses very similar words

*Correspondence to: Dr. Paul E. Neumann, Department of Medical Neuroscience, Faculty of Medicine, Dalhousie University, Halifax, Nova Scotia, Canada B3H 4R2. E-mail:paul.neumann@dal.ca

Received 28 October 2016; Accepted 3 November 2016

Published online 27 November 2016 in Wiley Online Library (wileyonlinelibrary.com). DOI: 10.1002/ca.22808 
TABLE 1. The Seven Rules of Anatomical Nomenclature

\begin{tabular}{|c|c|c|}
\hline Rule & Nomenclature commission (His, 1895) & IANC (1956) \\
\hline 1 & $\begin{array}{l}\text { Jeder zu benennende Theil soll nur einen Namen } \\
\text { haben. }\end{array}$ & $\begin{array}{l}\text { That, with a very limited number of exceptions, } \\
\text { each structure shall be designated by one }\end{array}$ \\
\hline 2 & $\begin{array}{l}\text { Die Namen müssen lateinisch und sprachlich } \\
\text { correct gebildet sein. }\end{array}$ & $\begin{array}{l}\text { That every term in the official list shall be Latin, } \\
\text { each country being at liberty to translate the } \\
\text { official Latin term into its own vernacular for } \\
\text { teaching purposes. }\end{array}$ \\
\hline 3 & $\begin{array}{l}\text { Ferner wird von von ihnen verlangt, dass sie } \\
\text { möglichst kurz und einfach seien. }\end{array}$ & $\begin{array}{l}\text { That each term shall be, so far as possible, short } \\
\text { and simple. }\end{array}$ \\
\hline 4 & $\begin{array}{l}\text { Die Namen sollen blosse Erinnerungszeichen sein, } \\
\text { und nicht den Anspruch auf Beschreibungen } \\
\text { oder auf speculative Interpretationen erheben. }\end{array}$ & $\begin{array}{l}\text { That the terms shall be primarily memory signs, } \\
\text { but shall preferably have some informative or } \\
\text { descriptive value. }\end{array}$ \\
\hline 5 & $\begin{array}{l}\text { Zusammengehörige Namen sollen möglichst } \\
\text { gleichartig zusammengesetzt sein (z. B. Femur, } \\
\text { A. femoralis, V. femoralis, N. femoralis). }\end{array}$ & $\begin{array}{l}\text { That structures closely related topographically, } \\
\text { shall, as far as possible, have similar names.... }\end{array}$ \\
\hline 6 & $\begin{array}{l}\text { Auch sollen Adjective im Allgemeinen ihre } \\
\text { Gegensätze zugeordnet haben (z. B. dexter, } \\
\text { sinister, major, minor, superficialis, profundus). }\end{array}$ & $\begin{array}{l}\text { That differentiating adjectives shall be, } \\
\text { in general, arranged as opposites.... }\end{array}$ \\
\hline 7 & $\begin{array}{l}\text { Wir haben nämlich für alle Theile sachliche } \\
\text { Benennungen aufgeführt, daneben aber } \\
\text { die allgemein verbreiteten persönlichen } \\
\text { Namen in Klammern beigesetzt. }\end{array}$ & $\begin{array}{l}\text { That eponyms shall not be used in the Official } \\
\text { Nomenclature of Gross or Microscopic Anatomy. }\end{array}$ \\
\hline
\end{tabular}

for mouth and bone. The two words have the same nominative singular form - Os - but the words are clearly different because other forms of these words differ, for example, the genitive singular forms of these words are Oris (of mouth) and Ossis (of bone). To reduce the chance of confusion, it is recommended that the official term for mouth be changed to the Greek-derived word Stoma.

Some of the apparent duplication of terms are not really violations of the previously unstated Rule 8 . Their appearance in books published by the IFAA is due to the use of a short form of the official term in these publications. Different entities may have the same short-form name, but their full names should be unique. The user guide of Terminologia Anatomica (1998) recognizes this problem and states "Often the full form of a term requires part of the names of previous mentioned structures." It gives an example: "Using Nodi profundi is not complete, the full name is Nodi lymphoidei poplitei profundi, and the English Deep nodes alone is not enough, the term is Deep popliteal lymph nodes."

TABLE 2. Proposed New Rules of Anatomical Nomenclature

\section{Rule}

$8 \quad$ That each name must be unique.

9

10

11 That each name shall consist only of nouns and adjectives.

That each name shall have only one noun in nominative case.

That the standard word order shall have nouns following the noun they modify, and adjectives immediately following the noun they modify.

That nouns in genitive case are generally preferable to adjectives when the modifier means "of" an entity, rather than "pertaining to" an entity.
The central theme of the nomenclature rules is that the term is a name, not a description or definition, and that the name should be short and simple. The proposed grammatical rules (9-12 in Table 2 ) are intended to further simplify and clarify Latin anatomical terms in a systematic way. Thus, they can be viewed as extensions of Rule 3.

Most of the terms in IFAA terminologies already conform to the proposed Rule 9. But some terms also include prepositions, conjunctions and adverbs, which are not essential parts of speech for the creation of a name. Thus there are no significant negative consequences to removing these parts of speech, and replacing them, if necessary, with nouns and/or adjectives. There are additional benefits. Eliminating prepositions, such as ad and cum, means that the IFAA terminologies no longer require the use of the accusative and ablative cases of nouns and adjectives. Knowledge of the nominative and genitive cases is sufficient.

Rule 10 is the proposed rule that will have the most obvious effect of shortening and simplifying a large number of terms. In Latin, the placement of two nouns, both in nominative case, next to each other is called apposition. One noun in this pair renames, defines or describes the entity named by the other. Thus one of the nouns is often redundant. In addition, translation of appositions into other languages can be challenging.

Because Latin is an inflected language, it can have a relatively free word order; however, the literal meaning of a phrase or sentence may be ambiguous because of the liberal syntax. The intent of Rule 11 is to reduce that ambiguity with a syntactical rule. This rule will make the hierarchical structure of the name clear, an obvious benefit for learners and translators. As consequences of this rule, words in nominative case will precede words in genitive case, and modifying words follow, as closely as possible, the noun they modify. 
TABLE 3. Application of Regular Anatomy (RA) Term Rules to Selected Anatomical Terms

\begin{tabular}{|c|c|c|c|}
\hline Official terms & Rules applied & RA terms & Ref \\
\hline Cavitas abdominis et pelvis & 9 (conjunction) & Cavitas abdominopelvica & TA \\
\hline $\begin{array}{l}\text { Cellulae serotonergicae vicinae nuclei } \\
\text { vestibularis medialis et nuclei prepositi }\end{array}$ & 9 (conjunction) & $\begin{array}{l}\text { Cellulae serotonergicae } \\
\text { areae vestibularis }\end{array}$ & TA \\
\hline Neuron parvum valde fluorescens & 9 (adverb) & $\begin{array}{l}\text { Neuron parvum fluorescens } O R \\
\text { Neuron parvum perfluorescens }\end{array}$ & $\mathrm{TH}$ \\
\hline $\begin{array}{l}\text { Ramus anastomoticus cum arteria lacrimali } \\
\text { [arteriae meningeae mediae] }\end{array}$ & 9 (preposition) & $\begin{array}{l}\text { Ramus anastomoticus lacrimalis } \\
\text { arteriae meningeae mediae }\end{array}$ & TA \\
\hline $\begin{array}{l}\text { R. communicans cum nervo } \\
\text { ulnari [nervi mediani] }\end{array}$ & 9 (preposition) & $\begin{array}{l}\text { Ramus communicans ulnaris } \\
\text { nervi mediani }\end{array}$ & TA \\
\hline $\begin{array}{l}\text { Ramus ad ganglion ciliare } \\
\text { [nervi oculomotorii] }\end{array}$ & 9 (preposition) & $\begin{array}{l}\text { Ramus ganglionaris ciliaris } \\
\text { nervi oculomotorii }\end{array}$ & TA \\
\hline Aditus ad antrum mastoideum & 9 (preposition) & Aditus antri mastoidei & TA \\
\hline Incisura sive Foramen frontale & 9 (conjunction) & Separate the alternate entities; & BNA \\
\hline Incisura frontalis/Foramen frontale & 9 (punctuation) & Separate terms & TA \\
\hline Pulmo dexter, lobus superior & 9 (punctuation) & Lobus superior pulmonis dextri & TA \\
\hline $\begin{array}{l}\text { Musculus levator labii superioris } \\
\text { alaeque nasi }\end{array}$ & 9 (conjunction) & Levator nasolabialis & TA \\
\hline Os ischium & 10 (apposition) & Os ischii OR Ischium & TA \\
\hline Musculus extensor carpi radialis brevis & $\begin{array}{l}10 \text { (apposition) } \\
11 \text { (ambiguous) }\end{array}$ & Extensor radialis brevis carpi & TA \\
\hline Musculus flexor digiti minimi brevis & $\begin{array}{l}10 \text { (apposition) } \\
11 \text { (ambiguous) }\end{array}$ & Flexor brevis digiti minimi & TA \\
\hline Stratum helicoidale brevis gradus & 11 (ambiguous) & Stratum helicoidale gradus brevis & TA \\
\hline Meatus nasi communis & 11 (ambiguous) & Meatus communis nasi & TA \\
\hline Nucleus amygdalae corticalis & 11 (ambiguous) & Nucleus corticalis amygdalae & TA \\
\hline Lobi renales & 12 ("of") & Lobi renis & TA \\
\hline Corpus gastricum & 12 ("of") & Corpus gasteris & TA \\
\hline
\end{tabular}

BNA - Basle Nomina Anatomica (His, 1895); TA - Terminologia Anatomica (FCAT, 1988); TH - Terminologia Histologica (FICAT, 2008).

Rule 12 is purposefully worded as a recommendation rather than a rule, because there will be many exceptions. The genitive noun is more restricted, thus clearer, in meaning than an adjective, and the formation of the genitive noun is usually simpler than declension of an adjective to agree in case, number and gender with the noun it modifies.

We call terms that conform to the expanded set of nomenclature rules Regular Anatomical (RA) terms, and recommend them as replacements for, or alternatives to, current official terms, if they differ. Terms that conform to RA term rules are much easier to analyze linguistically, to use as a basis for translation and to manipulate with computer programs, including expanding short form terms into full (unique) anatomical terms. Therefore, although Rules 9-12 (the RA term rules) have so far not been adopted by FIPAT or IFAA, RA terms will be added to the FIPAT databases and presented in future online terminologies along with the official terms. Some examples of possible changes due to application of RA term rules are presented in Table 3.

The proposed new RA term rules apply directly only to the Latin terminology. It is recommended that comparable rules should be followed when translating the Latin terms into other languages, in addition to observing the grammar (morphology and syntax) rules of that language.

\section{ACKNOWLEDGMENT}

The authors thank Drs. Alessandro Riva and John Fraher for reviewing the manuscript.

\section{REFERENCES}

FCAT (Federative Committee on Anatomical Terminology). 1988. Terminologia Anatomica. Stuttgart: Thieme.

FICAT (Federative International Committee on Anatomical Terminology). 2008. Terminologia Histologica. Philadelphia: Lippincott Williams \& Wilkins.

His W. 1895. Die Anatomische Nomenclatur. Leipzig: Verlag von Veit \& Comp.

IANC (International Anatomical Nomenclature Committee). 1956. Nomina Anatomica. Baltimore: Williams \& Wilkins.

ICN. 2012. International Code of Nomenclature for algae, fungi, and plants. Regnum Vegetabile 154. Lichtenstein: ARG Gantner Verlag KG.

ICNB. 1992. International Code of Nomenclature of Bacteria: Bacteriological Code. Washington: ASM Press.

ICZN. 1999. International Code of Zoological Nomenclature. 4th Ed. London: The International Trust for Zoological Nomenclature. 